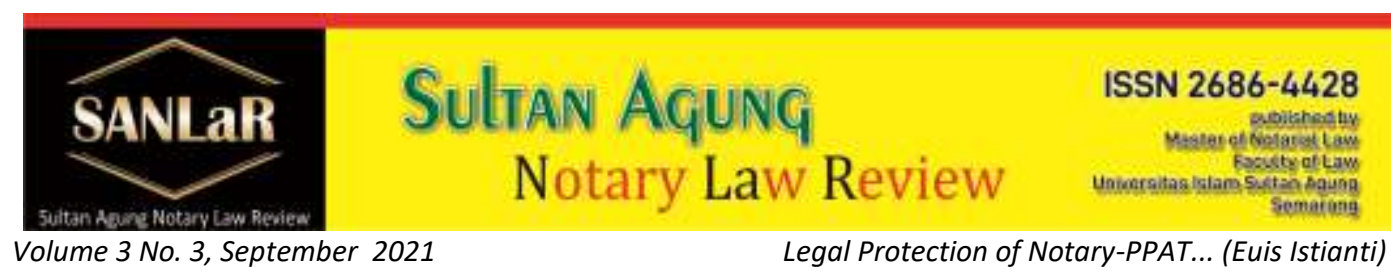

\title{
Legal Protection of Notary-PPAT in Making A Deed Based on False Information of Parties
}

\author{
Euis (stianti ${ }^{*}$ \\ ${ }^{*}$ Faculty of Law, Universitas Islam Sultan Agung (UNISSULA) Semarang, E-mail: \\ elistianti19@gmail.com
}

\begin{abstract}
The focus of this research has the following objectives: (1) legal certainty over the deed and the notary's responsibility for false statements of the parties; (2) legal protection for PPAT notaries who make a deed of sale and purchase based on false information from the parties. (3) an example of the waiver of rights if it turns out that there are false statements from the parties in accordance with article 51 paragraph 2 of the Criminal Code. This study uses a normative juridical research method, with the collection of literature study data, and the theory used is Hans Khelsen's Theory of Legal Protection. The results of the study conclude: (1) A notary deed will not have legal certainty if the notary as a public official (openbaar ambtenaar) who is authorized to make an authentic deed does not make a deed in accordance with applicable regulations or is carried out against the law. (2) Legal protection for a PPAT notary who makes a deed of sale and purchase based on the parties' false information is only based on the right of denial and good faith of the notary himself, if the notary does not have good faith, then the right of refusal does not apply. (3) Waiver of rights if it turns out that there is false information from the parties in accordance with Article 51 paragraph 2 of the Criminal Code, if the notary participates in the false information, then the notary cannot be free from punishment. Suggestions put forward: (1) The Public Prosecutor should add the related article into a claim in Article 264 Paragraph (1) in conjunction with Article 55 Paragraph (1) and 56 Paragraph (1) and Paragraph (2) of the Criminal Code. And there should also be a claim against the party who ordered to do this forgery and use this fake deed so that justice is truly served. (2) The Notary should be able to refuse requests from the appearers that are not in accordance with the provisions of the legislation, this is also a form of prudence of a Notary in order to avoid legal problems that will harm later. (3) Notaries should have and have good intentions to account for their actions.
\end{abstract}

Keywords: Protection; Deed; Information; Description; False.

\section{Introduction}

Article 1 paragraph (3) of the 1945 Constitution which states "The State of Indonesia is a state of law". this matterbased on the explanation of the 1945 Constitution that the Indonesian state is based on law (rechtstaat) and is not 
based on mere power (machstaat). Then the law has the highest position in government and the law is the protection of human interests ${ }^{1}$. The law regulates all legal relationships between individuals and individuals, individuals with society and individuals with the government. ${ }^{2}$ Therefore, the state should not carry out its activities on the basis of mere power, but must be based on law ${ }^{3}$. The regulation regarding the position of a Notary by the government refers to the principle that the Unitary State of the Republic of Indonesia is a legal state based on Pancasila and the 1945 Constitution of the Republic of Indonesia (UUD 1945) which aims to ensure certainty, order and legal protection, which is based on the truth. and justice ${ }^{4}$.

Notaries are referred to as Public Officials because they are appointed and dismissed by the general authority (government) and are given the authority and obligation to serve the public in certain matters, and therefore they participate in carrying out the authority of the government. ${ }^{5}$. Notaries as public officials are given the authority by the state to declare a legal relationship between the parties in a deed that records directly the clauses of the agreement of the parties who promise. The promise that has been stated in the deed is a reflection of the sincere will of the parties ${ }^{6}$.

The legal product issued by a notary is in the form of deeds which have an authentic nature and have perfect evidentiary power. As the definition of an authentic deed stated in article 1868 of the Civil Code is "An authentic deed is a deed drawn up in the form determined by law or before a public official authorized to do so at the place where the deed was made." Authentic deeds must meet what is required in Article 1868 of the Civil Code, are cumulative in nature or must cover everything. Deeds made, even though signed by the parties, do not meet the requirements of Article 1868 of the Civil Code, cannot be treated as authentic deeds, only have the power as written under the hand. ${ }^{7}$.

Notaries are often involved in legal cases both as witnesses and as suspects. The involvement of a Notary in a legal case is caused by an error in the deed he made, either because of the Notary's own fault or the fault of the parties or one of the parties who did not provide actual information or documents (the

\footnotetext{
${ }^{1}$ Sudikno Mertokusumo, 2003. Mengenal Hukum Suatu Pengantar, Liberty, Yogyakarta, 21.

${ }^{2}$ Mochtar Kusumaatmadja, 2000, Pengantar IImu Hukum Suatu Pengenalan Pertama Ruang Lingkup Berlakunya Ilmu Hukum, Alumni, Bandung, p.43.

${ }^{3}$ C.S.T. Kansil, 1986, Hukum Tata Negara Republik Indonesia, Bina Aksara, Jakarta, p.86.

${ }^{4}$ See the preamble to Act No. 30 of 2004 concerning the Position of a Notary.

${ }^{5}$ Soesanto, 1982, Tugas Kewajiban dan hak-hak Notaris, Pradya Paramita, Jakarta, p. 75.

${ }^{6}$ Putri A.R, 2011, Perlindungan Hukum Terhadap Notaris, PT. SOFMEDIA, Jakarta, p. 7.

${ }^{7}$ See Article 1869 of the Civil Code.
} 
existence of bad faith from the appearer) which caused harm to the other party. ${ }^{8}$

Bad faith is a willingness and or intention to do bad deeds, whether it is detrimental or beneficial to other parties. Not a few notaries who experience problems in connection with the deed they have made are declared to be an underhand deed or become null and void by a court decision as a result of finding a legal defect in its manufacture ${ }^{9}$.

Notary is an honorable profession and is always related to morals and ethics when carrying out his duties. When carrying out his duties, a notary holds fast and upholds the dignity of his profession as a position of trust and respect, because the ethics attached to the notary profession is called a noble profession (officium nobile). ${ }^{10}$. Notaries as public officials who carry out the profession in providing legal services to the public, need to get protection and guarantees in order to achieve legal certainty. The Republic of Indonesia is a constitutional state based on Pancasila and the 1945 Constitution which guarantees certainty, order and legal protection for every citizen. ${ }^{11}$.

Notaries in carrying out their positions and duties as public officials must have a sense of responsibility towards the State and society. For this reason, it is necessary to supervise the Notary in carrying out his position and authority so as not to deviate from the applicable laws and regulations. As a logical consequence, along with the notary's responsibility ${ }^{12}$ to the community, continuous supervision and guidance must be guaranteed so that the notary's duties are always in accordance with the legal rules that underlie his authority and can avoid abuse of authority or trust given. ${ }^{13}$. The main purpose of the supervision and development of the Notary itself is that all rights and authorities and obligations given to the Notary in carrying out his duties as given by the

${ }^{8}$ Christin Sasauw, Tinjauan Yuridis Tentang Kekuatan Mengikat Suatu Akta Notaris, Jurnal Lex Privatum,Vol. III/No. 1, 2015, p 100.

${ }^{9}$ A Chuasanga, Ong Argo Victoria. (2019). Legal Principles Under Criminal Law in Indonesia and Thailand, Jurnal Daulat Hukum, Vol 2, No 1 (2019) http://jurnal.unissula.ac.id/index.php/RH/article/view/4218 see Deen, Thaufiq., Ong Argo Victoria \& Sumain. (2018). Public Notary Services In Malaysia. JURNAL AKTA: Vol. 5, No. 4, 10171026. Retrieved from http://jurnal.unissula.ac.id/index.php/akta/article/view/4135

${ }^{10}$ Abdul Ghofur Anshori, 2009, Lembaga Kenotariatan Indonesia, Perspektif Hukum dan Etika, UII Press, Yogyakarta, p. 6.

${ }^{11}$ Widyatmoko, "Analisis Kritis Membedah Ketentuan Undang-undang Perubahan Atas Undangundang Nomor 30 Tahun 2004 (UUJN)", National Seminar, held by the Notary Masters Program, Faculty of Law, Sebelas Maret University, Surakarta, January 16, 2014, p.1.

12 Ong Argo Victoria, Ade Riusma Ariyana, Devina Arifani. (2020). Code of Ethics and Position of Notary in Indonesia. Sultan Agung Notary Law Review 2 (4), 397-407, http://lppmunissula.com/jurnal.unissula.ac.id/index.php/SANLaR/article/view/13536 see Yaya Kareng, Ong Argo Victoria, R. Juli Moertiyono. (2019). How Notary's Service in Thailand. Sultan Agung Notary Law Review, 1 (1), 46-56, http://jurnal.unissula.ac.id/index.php/SANLaR/article/view/4435

${ }^{13}$ Habib Adjie, 2012,Bernas-bernas Pemikiran di Bidang Notaris dan PPAT, Mandar Maju, Bandung, p.75. 
relevant basic regulations, are always carried out on a predetermined path not only by legal channels but also on the basis of moral and professional ethics to ensure legal protection and legal certainty for the community ${ }^{14}$.

A Notary can be a witness, a suspect or a defendant can arise, due to various reasons, it can be intentional or unintentional, but with any pretext, if proven guilty, the Notary has violated his own oath and added a fake deed for not carrying out his position properly. ${ }^{15}$. In the event that a notary is also summoned in a certain case, where he is made a witness or suspect or even a defendant, then to what extent is the protection he gets as a public official carrying out his office, whether he is processed in a manner generally in accordance with the Book of the Civil Procedure Code and the Criminal Procedure Code.

Article 16 paragraph (1) letter (e) of the UUJN states that a Notary is obliged to keep all information obtained in secret in order to make a deed in accordance with the oath or promise of office. This article is a regulation regarding the right of denial for a Notary, so that it can be used for a Notary in carrying out his oath of office.

The regulation on the secret of office is given by law to the Notary regarding the secret of his position contained in the oath of office Article 4 UUJN ${ }^{16}$, Article 16 letter $f$ UUJN and violations of the secret of this position are regulated in article 322 of the Criminal Code $^{17}$.

If the deed made by or before a notary has indications of a crime where the notary must relinquish or ignore the obligation to keep secrets related to the

\footnotetext{
${ }^{14}$ Putri AR, 2011,Perlindungan Hukum Terhadap Notaris-Indikator Tugas-Tugas Jabatan Notaris Yang Berimplikasi Perbuatan Pidana, Softmedia, Medan, p.49.

${ }^{15}$ Tan Thong Kie, 2000,Studi Notariat, PT. Ichtiar Baru Van Hoeve, Jakarta, 2000, p.262.

${ }^{16}$ Act No. 2 of 2014 concerning Amendments to Act No. 30 of 2004 concerning the Position of a Notary, Chapter II, article 4 paragraph 2, regarding the oath or promise of a Notary is affirmed as follows: "I swear/promise that I will obey and be loyal to the Republic of Indonesia. Indonesia, Pancasila and the 1945 Constitution of the Republic of Indonesia, the Law on Notary Positions and other laws and regulations. That I will maintain my attitude, behavior, and will carry out my obligations in accordance with the professional code of ethics, honor, dignity, and my responsibilities as a Notary. That I will keep the contents of the deed and information obtained in the execution of my position confidential. That I can be appointed to this position, either directly or indirectly, under any name or pretext, never and will not give or promise anything to anyone" and Article 16 paragraph (1) letter a of the UUJN that notaries are obliged to act honestly, thoroughly, independently, impartially, and protect the interests of related parties in making the deed. And Article 16 paragraph (1) letter e UUJN that the notary is obliged to keep all information obtained for the making of the deed in accordance with the oath/promise of office, unless the law provides otherwise.

${ }^{17}$ The Criminal Code, Chapter XVII, Article 322 paragraph 1, states that: "Anyone who intentionally discloses a secret that must be kept because of his position or occupation, both now and in the past, is threatened with a maximum imprisonment of nine months or a maximum imprisonment of nine months. a maximum fine of nine thousand rupiahs.
} 
contents of the deed because it is in the public or state interest as well as assisting the legal process, then Article 16 paragraph (1) letter e and Article 54 UUJN then confidential Position can be set aside if there are higher interests that require the Notary to give testimony or information so that the Notary is released from his oath of office in accordance with the applicable laws and regulations.

\section{Research Methods}

This study uses a normative juridical research method (normative legal research method). The normative juridical research method is a legal research library conducted by examining library materials or secondary data. ${ }^{18}$. By using the method of deductive thinking (a way of thinking in drawing conclusions drawn from something general that has been proven that he is right and the conclusion is intended for something specific) $)^{19}$.

\section{Result and Discussion}

\subsection{Legal Certainty on the Deed and the Notary's Liability for False Information of the Parties}

A notary as a public official (openbaar ambtenaar) has the authority to make an authentic deed, in connection with his authority the notary can be held legally responsible for his actions in making an authentic deed that is not in accordance with applicable regulations or is carried out against the law. Accountability is an attitude or action to bear all the consequences of the actions taken or an attitude to bear all the risks or consequences arising from an action.

The deed made by a notary must have certainty of content, certainty of date and certainty of the subject or person, where in the provisions of Article 1870 of the Civil Code it is stated that the authentic deed has absolute evidentiary power and binds the parties and applies as law for those who make it, so if there is a dispute between the parties who made the agreement, then what is stated in the deed is a binding and perfect evidence, it must be trusted by the judge, that is, it must be considered true (as long as the truth is not proven otherwise) and does not require additional proof. ${ }^{20}$

The notary must be able to assess the strength of the evidence from the deed he has made, where there are times when the power of outward

\footnotetext{
${ }^{18}$ Bambang Sunggono, 2003, Metodologi Penelitian Hukum, Raja Grafindo Persada, Jakarta, p. 2728.

${ }^{19}$ lbid, p. 13.

${ }^{20}$ R. Subekti, 2006, Pokok-Pokok Hukum Perdata, Internusa, Jakarta, p, 51.
} 
evidence is stronger than the power of formal and material proof. This is because the contents of the deed contain too many elements of legal action. A notarial deed made by deviating from the applicable provisions is a deed that contains legal defects and a deed like this according to Article 1869 of the Civil Code only has the power as evidence of an underhand letter if it is signed by the parties concerned. For example, a deed containing a legal defect is a deed made without the manufacturing procedure stipulated in Article 38 of the UUJN regarding the form and nature of the deed. The appearer does not meet the requirements as stipulated in Article 38 of the UUJN,

Based on this, the notary's responsibility for the deed he made must be supported by a moral will that can be accounted for. An authentic deed made by a notary means that the authentic deed is perfect evidence of what is made in it.

\subsection{Legal Protection for PPAT Notaries Who Make Deeds of Sale and Purchase Based on False Information of the Parties}

The complexity of the duties and use of notary rights in carrying out their duties, so they are needed to obtain legal protection, in this case a standard legal protection standard is highly expected. The duty and authority of the Notary Honorary Council is to examine the notary in connection with the request of the investigator, public prosecutor or judge to take a photocopy of the minutes or other documents attached to the minutes or in the notary protocol in the notary's depository, as well as to summon a notary related to the deed he made or in the notary protocol which is in the notary's storage ${ }^{21}$ The final result of the examination is the approval or rejection of the request of the investigator, public prosecutor or judge ${ }^{22}$.

The terms and procedures for taking the minutes of deed or photocopies of the minutes of deed and summoning a notary are regulated in the Regulation of the Minister of Law and Human Rights Number 7 of 2016 concerning the Honorary Council of Notaries. The notary may refuse to provide the minutes of his deed in the judicial process. However, this refusal does not necessarily say that the notary does not want to cooperate and assist the judicial process, but the notary only implements Article 16 Paragraph (1) Letter B of Act No. 2 of 2014 concerning Amendments to Act No. 30 of 2004 concerning Notary Positions, which stipulates that the notary is obliged to keep the minutes of the deed based

\footnotetext{
${ }^{21}$ Article 66 of Act No. 2 of 2014 concerning Amendments to Act No. 30 of 2004 concerning the Position of Notary.

22 Ibid.
} 
on Article 1 Number 13 of Act No. 2 of 2014 concerning Amendments to Act No. 30 of 2004 concerning the Position of a Notary, which is a state archive.

According to Habib Adjie that, notaries hope to get proportional protection in carrying out their duties as a notary, at least there will be a fair and transparent and scientific examination when the examining board at the Regional Notary Honorary Council examines the notary at the request of the police, prosecutors, or other notaries. court $^{23}$.

According to Habib Adjie that, notaries hope to get proportional protection in carrying out their duties as a notary, at least there will be a fair and transparent and scientific examination when the examining board at the Regional Notary Honorary Council examines the notary at the request of the police, prosecutors, or other notaries. court ${ }^{24}$.

The existence of a notary authority granted by the Law on the Position of Notary, relating to the material truth of the authentic deed, if it is carried out without caution so as to endanger the community and or cause harm, whether done intentionally or not and the act is threatened and or fulfills the elements criminal act, the notary must be held criminally responsible for the act.

This concept shows that there is a compromise between written law as a requirement of the legal community for legal certainty and living law as a manifestation of the formation of the important role of society in the formation and orientation of law. ${ }^{25}$. The actualization of living law is that law is not seen in the form of rules but its development in society itself.

3.3. Example of Waiver of Rights if it turns out that there is false information from the parties in accordance with Article 51 Paragraph 2 of the Criminal Code

The main authority of a Notary is to make an authentic deed in accordance with the authority given to him so that the deed can have perfect evidentiary power, in other words it has the highest position as written evidence, because a Notary is an official appointed by law to act as a public official for carry it out. And the authority and implementation of this authority is regulated by law so that the Notary in carrying out his duties and responsibilities cannot escape the existing provisions. If the Notary deviates from the existing provisions, the deed will no longer be authentic.

\footnotetext{
${ }^{23}$ Habib Adjie, Op. Cit, p.228.

${ }^{24}$ Ibid.

${ }^{25}$ Lili Rasjidi dan Putra, I. B. Wiyasa, Hukum Sebagai Suatu System, Remaja Rosdakarya, Bandung p. 7.
} 
And result in the Notary concerned being subject to sanctions if there are parties who sue or report it.

The act of counterfeiting an authentic deed carried out by a Notary can fulfill the elements of an unlawful act in Article 1365 of the Civil Code and opens the possibility of filing various claims, namely: a claim for compensation, a statement as law, an order or prohibition by a judge, and this can apply to a Notary as an example. if it is proven to have committed an unlawful act which causes the deed to be null and void or to be cancelled.

For a Notary who commits a criminal act, the Minister may dismiss him on the grounds that the Notary has been proven guilty and is subject to imprisonment, which is regulated in Article 21 Paragraph 2 sub-chapter b of the Decree of the Minister of Justice and Human Rights of the Republic of Indonesia Number M-01.HT.03.01 2003 concerning Notaries, namely that a Notary is proven guilty in direct connection with his position or other criminal acts with a penalty of 5 (five) years in prison.

A criminal act is an act that is prohibited in a rule of law, where the prohibition is also accompanied by sanctions or threats in the form of certain criminal sanctions for those who violate. Criminal provisions are not regulated in UUJN, but in terms of criminal responsibility, a Notary who commits a criminal act may be subject to sanctions against the Notary. In UUJN, it only regulates sanctions for violations committed by a Notary in the form of a deed that does not have authentic power or only has proving power as an underhand deed which, against a Notary, can be given a sanction in the form of a warning to dishonorable dismissal.

UUJN does not regulate explicitly and in detail regarding Notaries who commit criminal acts in connection with their positions, so that criminal acts committed will still refer to the Criminal Code, because UUJN only regulates sanctions for the Code of Ethics, Civil and Administrative. A Notary who is dishonorably dismissed because of a violation in the event that the Notary has been sentenced to imprisonment based on a court decision that has permanent legal force for committing a crime against his deeds (forgery) and sentenced to imprisonment with a threat of 5 (five) years or more then the protocol is submitted to another Notary appointed by the minister at the proposal of the Central Supervisory Council.

In Article 51 Paragraph (2) of the Criminal Code (performing an unauthorized position order but is considered valid). Unauthorized position orders are summarized in Article 51 Paragraph (2) which states: An order of office without authority does not result in the abolition of the crime, unless the one who is ordered, in good faith thinks that the order is given 
with authority and is carried out within his work environment.

In essence, an illegal position order does not abolish the perpetrator's punishment. Therefore, in order for an unauthorized position order to function as an excuse for forgiveness, three conditions must be met. First, the order is seen as a legitimate order. Second, the order was carried out in good faith. Third, the execution of the order is within the scope of his work."

\section{Closing}

Journals:

[1] A Chuasanga, Ong Argo Victoria. (2019). Legal Principles Under Criminal Law in Indonesia Dan Thailand, Jurnal Daulat Hukum, Vol 2, No 1

(2019) http://jurnal.unissula.ac.id/index.php/RH/article/view/4218

[2] Alam, Bahrul., \& Khisni, Akhmad. (2020). Legal Protection of Holders of Land Loss Data In The City Land Office of Kendari. JURNAL AKTA: Vol.7, No. 2, 159-164. Retrieved from http://jurnal.unissula.ac.id/index.php/akta/article/view/7963

[3] Arrohim, Mohammad B., \& Wahyuningsih, Sri Endah. (2020). Analysis of Judicial Application of Criminal Penalty Against Notary / Land Deed Officials Conducting Making Crime of the Fake Authentic Deed in State Court of Semarang. JURNAL AKTA: Vol.7, No. 2, 183188. Retrieved from http://jurnal.unissula.ac.id/index.php/akta/article/view/7891

[4] Christin Sasauw, Tinjauan Yuridis Tentang Kekuatan Mengikat Suatu Akta Notaris, Jurnal Lex Privatum,Vol. III/No. 1, 2015.

[5] Deen, Thaufiq., Ong Argo Victoria \& Sumain. (2018). Public Notary Services In Malaysia. JURNAL AKTA: Vol. 5, No. 4, 1017-1026. Retrieved from http://jurnal.unissula.ac.id/index.php/akta/article/view/4135

[6] Ong Argo Victoria, (2018) Waqf Al-Nuqūd In Indonesia (In Law Perspective), Jurnal Pembaharuan Hukum Vol 5, No 1 Universitas Sultan http://jurnal.unissula.ac.id/index.php/PH/article/view/2999 Agung,

[7] Sukarmi, S., \& Victoria, A. (2018). Cash Waqf in Sustaining of Indonesian Society "In Legal \&amp; Economic Perspective". ALITQAN: JOURNAL OF ISLAMIC SCIENCES AND COMPARATIVE STUDIES, 2(1), 83-97. https://doi.org/10.31436/al-itqan.v2i1.43

[8] Widyatmoko, "Analisis Kritis Membedah Ketentuan Undang-undang 
Perubahan Atas Undangundang Nomor 30 Tahun 2004 (UUJN)", Seminar Nasional, diselenggarakan Program Magister Kenotariatan Fakultas Hukum Universitas Sebelas Maret, Surakarta, 16 January 2014.

Books:

[1] Abdul Ghofur Anshori, 2009, Lembaga Kenotariatan Indonesia, Perspektif Hukum dan Etika, UII Press, Yogyakarta.

[2] Bambang Sunggono, 2003, Metodologi Penelitian Hukum, Raja Grafindo Persada, Jakarta.

[3] Habib Adjie, 2012,Bernas-bernas Pemikiran di Bidang Notaris dan PPAT, Mandar Maju, Bandung.

[4] Kansil, C.S.T., 1986, Hukum Tata Negara Republik Indonesia, Bina Aksara, Jakarta.

[5] Lili Rasjidi dan Putra, I. B. Wiyasa, Hukum Sebagai Suatu System, Remaja Rosdakarya, Bandung.

[6] Mochtar Kusumaatmadja, 2000, Pengantar Ilmu Hukum Suatu Pengenalan Pertama Ruang Lingkup Berlakunya IImu Hukum, Alumni, Bandung.

[7] Putri AR, 2011,Perlindungan Hukum Terhadap Notaris-Indikator Tugas-Tugas Jabatan Notaris Yang Berimplikasi Perbuatan Pidana, Softmedia, Medan.

[8] Putri A.R, 2011, Perlindungan Hukum Terhadap Notaris, PT. SOFMEDIA, Jakarta.

[9] Soesanto, 1982, Tugas Kewajiban dan hak-hak Notaris, Pradya Paramita, Jakarta.

[10] Subekti, R., 2006, Pokok-Pokok Hukum Perdata, Internusa, Jakarta.

[11] Sudikno Mertokusumo, 2003. Mengenal Hukum Suatu Pengantar, Liberty, Yogyakarta. 
[12] Tan Thong Kie, 2000, Studi Notariat, PT. Ichtiar Baru Van Hoeve, Jakarta, 2000. 